\title{
Auto-stereotypes and Hetero-stereotypes in Slovene and Italian Poetry About Trieste From the First Half of the $20^{\text {th }}$ Century
}

\author{
ANA TOROŠ
}

\begin{abstract}
This article brings to light the socio-political conditions in the Triestine region, at the end of the $19^{\text {th }}$ century and in the first half of the $20^{\text {th }}$ century. These conditions influenced the formation of stereotypical, regionally coloured perceptions of Slovenes and Italians in the Slovene and Italian poetry about Trieste from the first half of the $20^{\text {th }}$ century, which were specific to the Triestine area or rather the wider region around Trieste, where the Slovene and Italian communities cohabited. This article also points out that these stereotypes are constructs. The Italian Triestine literature most frequently depicted the Italians (native culture) before the First World War, in accordance to the needs of the non-literary irredentist disposition. In this light, it depicted them as the inheritors of the Roman culture, wherein it highlights their combativeness and burning desire to "free" Trieste from its Austro-Hungarian prison. An increase in auto-stereotypes among the Slovene poetry is noticeable after the First World War and is most likely a consequence of the socio-political changes in Trieste. The Slovene Triestine literature depicted the Slovenes (native culture) after the First World War as "slaves" and simultaneously as the determined defenders of their land, who are also fully aware of their powerlessness against the immoral aggressor and cruel master (Italian hetero-stereotype) and so often call upon the help of imaginary forces (mythical heroes and personified nature in the Trieste region) and God. The Italian Triestine literature mostly depicted the Slovenes before the First World War as an inferior people, often referred to by the word "ščavi". After the First World War, the Slovenes are depicted merely as the residents of the former Austro-Hungarian Trieste, meaning they were part of the narrative surrounding Trieste, only in when the narrative was set before the First World War. In this case, pre-war Slovene stereotypes appear, also depicted as part of the literary myth of the "Habsburg" Trieste, namely as the folkloric characters from the surrounding countryside.
\end{abstract}

Keywords: Simon Gregorčič; Anton Aškerc; Triestine literature; Igo Gruden; Janko Samec; Carlo Mioni; Umberto Saba; Dragotin Kette 
At the end of the $19^{\text {th }}$ century and the beginning of the $20^{\text {th }}$ century before the First World War, Trieste was an important Austro-Hungarian seaport, within which the Slovene and Italian communities played recognisable parts.

During the mentioned timeframe, the cultural and economic importance of the Slovenes soared. The Slovene National Hall in Trieste, which opened its doors in 1904, became the symbol of the Slovenes' presence in the city. It was a modern multi-purpose building, designed by the famous architect Maks Fabiani. It was set up in the very centre of the city, in today's Oberdan Square. Many a Slovene society found space for their headquarters there.

The Slovenes wished to call attention to their presence and importance within the city through the said building. During that time, Trieste was the biggest Slovene city in terms of its number of inhabitants - today's capital of Slovenia, Ljubljana, has fewer Slovene inhabitants than Trieste in those days. The Slovenes were the second largest community in Trieste before the First World War, the largest being the Italians. Furthermore, the surrounding countryside was predominantly Slovene. ${ }^{1}$

The Slovene depiction of Trieste as the hub of Slovene culture was in direct contrast to the aspirations of the city's Italian community, which had been fostering the idea of Trieste merging with the Kingdom of Italy since the latter half of the $19^{\text {th }}$ century. ${ }^{2}$

The Italian Triestine poetry played an integral role in reinforcing the idea of Trieste as a future Italian city. The ideology upon which it was based stemmed from the notion of Italians as the inheritors of Roman culture and on the archaeological discoveries of Trieste as a former Roman colony. Based on this, Italian Triestine poets depicted the literary image of a "Roman Trieste", simultaneously endorsing the call for Trieste to merge with the Kingdom of Italy, as the successor of the Roman Empire.

The literary image of the "Roman Trieste" was normally connected to St. Justus' Hill, which towers over the main square of Trieste. Upon the hill, archaeologists found remains from the time of the Romans. Due to this, the hill was often the setting of many an Italian Triestine poem before the First World War.

After the First World War, the Italian Triestine poets were focused on creating a different literary image of Trieste, one of the idealised "Habsburg Trieste", through which they infused their nostalgia for the life in Trieste during the decades before the First World War. ${ }^{3}$ The motif of St. Justus' Hill was therefore

For more about the population census of Trieste in 1910 see: Pletikosić 2006.

For more about Italian irredentism see: Vivante 1984.

For more on the literary image of the "Habsburg Trieste" see: Toroš 2011. 
TOROŠ

less common during the interwar period. In the instances it does appear, it repeats the prewar literary pattern of declaring the Italians as the successors of Rome. A typical example of such a literary pattern can be observed in this excerpt of Raimondo Cornet's (1887-1945) poem San Giusto:

San Giusto xe l'orgoglio de ste tere,

xe 'l Campidoglio triestin; insoma,

traverso el tempo e tiranie straniere

el ricorda che semo fioi de Roma.

Parla sul colle i ruderi romani

resti de templi e muri de difesa -

$[\ldots]$

tempi antichi vizin a tempi novi, tuti del stesso italico respiro!

(Cornet 1938: 18-20). ${ }^{4}$

Concurrent with the creation of the Italian literary image of Trieste as a former (and future) Roman city, the personification of the city as a beautiful girl named Trieste was created, an Austro-Hungarian prisoner and fiancée to an Italian prince. Trieste is depicted either as a helpless girl, awaiting her prince to save her, or as a warrior, striving for freedom and marriage to the beloved prince. The latter was employed by the poetess Maria Gianni in her poem L'attesa ('Awaiting'), most likely penned just before the Italians took over the city. She writes:

Trieste come sposa innamorata:

dopo i lunghi anni d'insofferto bando

attende ancora la sua gran giornata.

O Roma, o Italia, o Patria unica e grande,

nelle tue mani il fato nostro sta:

con quell'ardore che dal cuor s'espande

Trieste i figli e l'avvenir ti dà

(Gianni 1919: 21). ${ }^{5}$

4 Saint Justus is the pride of this land, / it's the Triestine Capitoline, as / through the ages and foreign tyranny/ it reminds us that we are the sons of Rome. / Upon the hill the ruins speak, / the remainders of temples and defensive walls - [...] in the past and today, / the same Italic air pervades!

5 Trieste as an enamored bride: / after the long years of suffering since the announcement / she waits still for her big day. / Oh Rome, Oh Italy, Oh homeland great and only, / in your hands our fate lies, / with our hearts' ardor growing, / Trieste will give you her sons and future. 
Along with the presented literary images (Trieste as the jailed Italian bride, a Roman Trieste), antagonistic, negative roles were gaining ground, of those who opposed the marriage between Trieste and the Italian prince and so subsequently would endanger the vision of an Italian Trieste. These literary antagonists were the Slovenes.

The literary image of the Slovenes as created in the Italian Triestine poetry emerged as an enemy of the Italian Trieste. Consequently, they were depicted in a negative light. These were not the neighbours or fellow citizen with whom the Italian protagonists were friends. Their commercial ties were not mentioned, either, although they did exist during the Austro-Hungarian Empire. In those days, the Slovenes were known in Trieste for being fishmongers and selling homemade products, especially on the Ponte Rosso market, named after the nearby red drawbridge. ${ }^{6}$

A passage by Slovene poet Anton Aškerc captures such an interaction, written towards the end of the $19^{\text {th }}$ century, while he lingered in the Trieste region and spent some time among the Slovene fishmongers. In the poem Školjka ('Seashell'), he speaks of the romantic spark that jumps between a Slovene fishmonger and an Italian $(\text { lah })^{7}$ girl from Trieste:

\section{Takšno lice rožnato imelo včeraj v Trstu laško je deklè! \\ Rib je kupila od mene signorina mlada, lepa - da! (Aškerc 1989: 189) ${ }^{8}$}

Instead of these literary imaginings of Slovene-Italian interactions, we find in Italian Triestine poetry another design, one that accentuates the divide between the communities, so that two separate groups emerged onto the literary scene: "we" (the Italian protagonists) and "they" (the Slovene antagonists). The former were the advocates for an Italian Trieste, the latter were advocates for a Slovene Trieste.

An example of such an ideological literary discourse can be found in Odoardo Weiss' poem 'Na volta e adesso ('Once and Today'):

6 For more about the Ponte Rosso see: Bezin 2012.

7 The word lah is a traditional Slovene word for an Italian and took on a negative connotation only at the onset of the First World War (Stergar 2005: 108). Aškerc uses the word without the negative connotation.

8 Such rosy cheeks had / yesterday the lah girl in Trieste! / from me she bought fish / young mademoiselle, beautiful - yes! 
TOROŠ

I nostri cari noni

I scazava nazai

A colpi de bastoni

Quei prodi del zakai.

$[\ldots]$

In zità i vien urlando:

$[\ldots]$

Ja, zivio Trst slovenska

(Weiss 1909: 64-65). ${ }^{9}$

As seen in the example above, the Slovene literary characters, the enemies of the Italian Trieste, were stereotypical, with namely two fundamental characteristics highlighted and depicted in a negative light: language and culture. They were depicted as the antithesis to the Roman Trieste, as a second-class people, who endangered the idea of an Italian Trieste, and who through their very language, substantiated the idea of a Slovene Trieste. Consequently, the sentiment of "phobia" (Pageaux 2005: 19) towards the Slovenes in Italian Triestine poetry before the First World War was revealed through their rejection of the Slovene language.

Odoardo Weiss' quoted excerpt shows the inaccurate use of the chosen Slovene words. The spelling does not follow Slovene orthography, it most likely strives to merely imitate the pronunciation of the Slovene words: nazaj (nazai / back), zakaj (zakai / why), živijo (zivio / hello). The name Trieste is gendered as masculine in Slovene (tisti Trst), but the poet uses the Italian pattern of feminine gendering (quella Trieste) in the poem (tista Trst). These warped uses of Slovene words most likely stem from an insufficient knowledge of the language while also revealing the feeling of superiority towards the Slovene culture.

Remnants of such negative portrayals of the Slovene language can be found even after the war. Carlo Mioni, one of the most prolific Italian Triestine authors in the interwar period, remembers the city's unwanted "Slovenisation" before the First Wordl War, which was effectively halted after the Italians took over the city:

Perchè tentava i 'scavi

Qua farla de paroni

$[\ldots]$

Za zerti botegheri

Meteva le tabele

Par crico o in dopia lingua

9 "Our dear grandfathers / drove away / with the might of clubs / the audacious who say 'zakaj'. [...] They come to town calling out: [...] Yes, hello Trieste Slovene.” 
Auto-stereotypes and Hetero-stereotypes in Slovene and Italian Poetry About Trieste

$[\ldots]$

I libri tavolari

Sporcai con pipe e "ici"

(Mioni 1933: 28). ${ }^{10}$

As seen in the example above, the presence of the Slovenes in the city before the First World War was reflected in the increasing numbers of signs in Slovene, characterised by letters for postalveolar consonants, that had carons ( $(\check{c}, \check{z}, \check{s})$. The letters attracted the Italians' attention as the Italian alphabet does not have these letters. The Slovenes, in Italian Triestine poetry from that era, were sometimes addressed as pipa, which is the Italian word for the caron (diacritic mark). ${ }^{11}$ More often they were called ščavi, ${ }^{12}$ as in Carlo Mioni's poem. This term labelled the Slovenes as lesser than Italians, in terms of cultural backwardness and economic and political inferiority.

To conclude, the presented literary imagery of the Slovenes from the pages of Italian Triestine poetry was not striving for an accurate portrayal of the Slovenes in Trieste, as they evolved from specific political needs. Italian poets used this imagery to build and reinforce among their readers the notion of Slovenes being dangerous individuals, who could quite possibly disrupt Trieste's marriage to the Italian prince (Trieste merging with the Kingdom of Italy). And so, the battle between the Slovene and Italian sides was unfolding in Trieste through the Italians' poetry even before the First World War and the onslaught of fascism.

Proof that the literary imagery of Slovenes in Italian Triestine poetry was a construct is provided by the fact that the Italians abandoned the said construct as soon as the war ended and Trieste was made Italian. The Slovenes no longer posed a threat to the irredentist dreams, and with the onslaught of fascism and the Italianisation policy, or rather the intentional assimilation of the Slovene people, the "Slovene element" had to be completely purged from Trieste-based Italian literature. ${ }^{13}$

10 "Because the ščavi tried / to rule here [...] Already some shopkeeps / put up signs / bilingual or in German [...] The land registers / were sullied by the carons and the 'iči'."

11 More on this: Doria 1988.

12 Ščavo (It. schiavo, slave, Slav), a scornful Italian word for a Slovene, Croat and other Slavs (Tavzes 2002: 1118). The Dictionary of the Standard Slovene Language describes the word as being a derogatory term for a Slovene or Yugoslavian, used in the Italian area, sometimes used as a slur.

13 More on the assimilation policy for Slovenes in the Triestine area during the fascist era, see: Kacin Wohinz 2000. 
TOROŠ

In keeping with the political measures put in place in the 1920s and 30s, depictions of Slovenes were completely deleted from the pages of Italian Triestine poetry - meaning, the Slovenes were deleted from the Triestine territory. Consequently, the previously common division of literary characters as "we" (the Italian protagonists) and "they" (the Slovene antagonists) was no longer suitable. Instead, a new literary model developed where the literary characters were Italian or rather their national identity was not the subject of depiction. Additionally, the setting of the Triestine area was idealised: it was no longer the stage for national tension, but an idyllic coastal region, suitable for romantic alliances and other light-hearted topics.

The Italian Triestine poetry of the interwar period still supported the idea of an Italian Trieste, despite the seemingly apolitical stance, and so predicted the desired, future, Italian image of the Trieste region.

Two sonnets, set in the coastal village of Barkovlje (Italianised Barcola) on the outskirts of Trieste, can be used as examples. The first, entitled Barcola was written by the afore mentioned Carlo Mioni (1871-1946) and published in 1934. The second one was written by Slovene author Igo Gruden (1893-1948) and published in 1920 . Both the sonnets were therefore penned by poets born and living in Trieste and who belonged to the same generation of poets. Despite all this, their sonnets illuminate their contrasting views of Barkovlje:

Carlo Mioni: Barcola ${ }^{14}$

Un mucio de vile stivade

Sul monte o de soto specia,

De bianco e rosè piturade

Nel mar verde blu. D’una vecia
Igo Gruden: Barkovlje ${ }^{15}$

Kot bi pred burjo se v zavetje skrile na begu ptice - v bregu bele hiše na paštne, kjer od morja veter diše med trte so in oljke se spustile.

14 A huddle of houses upon the hill or beneath are reflected / bathed in pink and white / in the blue green ocean. / the confused bells of an old church sing. / A weeping bucket emerges from a well. / The sails explain, the boats weave past each other in the silver bay. / Bathed in light, flame and colour / the enchanted castle below / cavorts in a flowery meadow / under a fragrant arbour / two heart vow to love one another.

15 As the fleeing birds would take shelter / from the bora - on the white house's slope / on the terraces, where the sea wind blows / they land between the grapevines and olive trees. / before them, the Barkovlje women laid out / white shirts ... a little higher in the sun / above the trellises, in the windows carnations redden / whose hands sewed it there? / A man struggles in the Škedenj blast furnace / in the Trieste port a boy carries sacks / a girl offers flowers on the Red Bridge: / from Barkovlje, where my language is not fading / because the land did not feed the traitors / our blood and land is pouring into Trieste. 
Auto-stereotypes and Hetero-stereotypes in Slovene and Italian Poetry About Trieste

Cieseta campane sfazade

Che canta. Pianzendo una secia

Vien fora de un pozo. Spiegade

Le vele le barche se intrecia

Nel golfo de argento. 'Nondado

De luse, de fiame e colori

Zo in fondo el castel incantado

Ziveta fra un bosco de fiori,

E soto un glorièt profumado

De amarse se giura do cuori

(Mioni 1934: 31).
Pred njimi Barkovljanke razgrnile so bele srajce ... v soncu malo više nad latniki po oknih nagelj rdi še za koga roke so ga tja vsadile?

Mož v plavžih škedenjskih ves dan se trudi, $v$ tržaški luki žaklje fant prenaša, deklé na Rdečem mostu rože nudi:

iz Bárkovelj, kjer moj jezik ne ugaša, ker izdajic dojile niso grudi, zajeda v Trst se kri in zemlja naša (Gruden 1920: 43).

As we can see, in the sonnet Barcola, Mioni puts the aesthetic experience and romantic spark into the foreground, with no dramatic aspect. The sonnet's atmosphere resonates with the calm beauty and the peaceful tone of the coastal village.

Contrastingly, Igo Gruden's sonnet focuses on the villagers, highlighting their poor social standing, alluding to nationalistic repression and also emphasizing how the Slovene culture is rooted in the Triestine land. In the first tercet, the poet references some of the vocations that Barkovlje villagers were working in: dockworkers at the Port of Trieste and workers at the blast furnace in Škedenj (it. Servola), a quarter in Trieste. Also mentioned are the Slovene women, who used to sell their produce on the main market square, the Red Bridge. Kruharice (bread-ladies) were known for selling homemade bread, and Gruden mentioned rožarice (flower-ladies) who sold flowers in the city. The poet subtly reveals the repression of the Slovene people at the hands of the new Italian regime. It was in 1920 that the Slovene National Hall in Trieste was burned down by those opposed to the Slovene community. ${ }^{16}$ This event was often depicted in the following years by Slovene authors, and so the National Hall became a symbol of the former Slovene culture in Trieste. We can recognise the subtle critique of the existing conditions in the last tercet, wherein the first-person plural subject is broadcasting (to an unidentified antagonist, most likely the new Italian government in Trieste) on behalf of the Slovene community that they are united ("ker izdajic dojile niso grudi") and deeply rooted in the Triestine land, unable to be Italianised ("iz Bárkovelj, kjer moj jezik ne ugaša” - the Slovene language is not fading, the language of the Slovene community).

${ }_{16}$ More on the arson of the National Hall, see: Kacin Wohinz 2000: 29. 
TOROŠ

From the analysis above we can gather that Italian poetry from that era was not alone in being the medium through which communities solidified their national identity in the Triestine area, as the Slovene Triestine poetry had a similar function. The difference was in the method of self-representation: while the Italians depicted themselves as the spirited and energetic inheritors of Roman culture in Trieste, the Slovenes predominantly depicted themselves as the defenders of Trieste, their homeland.

This kind of Slovene auto-stereotype, linked to the Triestine area, can already be found in the works of two Slovene authors, Anton Aškerc and Simon Gregorcič, at the end of the $19^{\text {th }}$ century. Both authors wrote about bloody battles between the Slovenes and Italians taking place in the Triestine region or in its immediate vicinity, sparked by the invasion of the Slovene land by the Italians. In Balada o Čožotih ('The Chioggians' Ballad'), Anton Aškerc describes the life of Slovene Triestine fishermen, whose fishing zone was being infiltrated and fish stolen by Italian (Chioggian) ${ }^{17}$ fishermen. This sparked a rebellion among the Slovene fishermen, as they wanted to protect their fishing ground. The Italians' offensive verbal abuse and use of the slur ščavi especially fired up the Slovene fishermen's anger: “Čožoti, / kazali nam osle, / pitali nas s 'ščavi', / kadar so veslali / drzni mimo nas"18 (Aškerc 1989: 176). Due to all of this, the Slovene fishermen wished to drive away their Italian neighbours, igniting a bloody sea battle, resulting in casualties on both sides.

A similar motif was used by the poet Simon Gregorčič in his poem Soči ('To the Soča'). The poem, dedicated to the River Soča, sings praise to the beauty of her flow, from her mountain source to her river mouth. Along the riverside live the Slovenes, but they are threatened by "a horrible storm" which will "storm in from the warm south" (Gregorčič 1947: 65-67). Gregorčič is alluding to Trieste merging with the Kingdom of Italy and the progressively louder calls for irredentism, and the wishes for other areas were Italian communities lived, still under the Austro-Hungarian Empire, to join them in the new Italian country. The poet describes the Italian nation as being "ravenous for land" and firmly gives his support to the Slovenes. They will soon have to fight for their land, like the fishermen in Aškerc's The Chioggians' Ballad. In Soči, Simon Gregorčič prophesied the bloody battle between the Slovenes and Italian in that area, which subsequently took place during the First World War and in the fascist era. It must not be overlooked how Gregorčič personifies the river, he pleads with her as a Slovene mother, to take care of her Slovene sons and drown in her waters the greedy foreigners (Italians).

\footnotetext{
17 Italian fishermen from Chioggia, a town near Venice (Volpi Lisjak 2010: 93).

18 Chioggians, / taunted us, / calling us 'ščavi’ / as they rowed / boldly past us.
} 
Evidently, both poems have a similar narrative structure, which could be labelled as the storytelling model which the bulk of Slovene Triestine literature followed. Both poems are set within the Triestine area, where a Slovene community lives, and a clear division between "we" (the Slovenes) and "they" (the Italians). In this case, the native (Slovene) culture is depicted as a peaceloving and self-sufficient or rather self-contained and having very high moral values. The source text gives no indication that they are interested in the foreign (neighbouring, Italian) culture, nor that they know anything of their cultural heritage or even wish to learn the specifics of their culture. On the other hand, it shows no aggression towards the foreigners or any wish for conquering their land. A more accurate sentiment would be helplessness and fear of an imminent attack. Out of this helplessness they turn to pleading for help against the unfair foreign (Italian) nation. The plea is addressed to an authority far exceeding mortals (the Christian God, mythological heroes, local nature personified). The native (Slovene) culture turns to God as an unbiased arbiter, a "father" who will save his "sons" from evil (the foreign culture is depicted as a morally depraved society, the harbinger of evil or rather the personification of evil). A similar role is taken on by the river (River Soča) as a fair "mother" who will help her "sons" in the battle against the foreign invaders.

A possible encouragement to the Slovene self-image (as a religious community) was the fact that both Gregorčič and Aškerc were priests and that the Catholic Church had a noticeable political and cultural role throughout the Slovene ethnic space in that era.

The two aforementioned poems are an exception in the opuses of the two poets, as they both mostly devoted their work to other topics. Nevertheless, the storytelling model prevailed among the next generation of Slovene poets from the Triestine region and the surrounding Slovene countryside, which was under the Italian flag from the end of the First World War.

Until the First World War, Slovene authors from Trieste did not problematise the Triestine socio-political situation in their works, as the conditions were not dire or worrying for the Slovenes, in the sense that the medium of literature had to report it or rather that it would present dramatic material for literary treatment. After the First World War and the onslaught of fascism in the Triestine region, the situation changed markedly, symbolised by the burning of the National Hall in 1920. This event can be labelled as a motivic-thematic milestone in Slovene Triestine literature, as after this, Slovene Triestine authors almost exclusively built their narratives around the mentioned scheme of division between "we" (the Slovenes) and "they" (the Italians). 
TOROŠ

The exceedingly intense socio-political situation in Trieste during the fascist era had the Slovene authors referencing the 'others' (Italian antagonists) indirectly, through allusions, metaphors, metonymies and similar figures of speech.

A good example is this excerpt of a longer poem from 1921 entitled Kobletnici 13. julija ('For July $13^{\text {th }}$ Anniversary'). As revealed in the title, the poem was penned in remembrance to the arson in the National Hall in Trieste on July $13^{\text {th }}$, 1920. The poem was written by the Slovene Triestine poetess Marica Gregoric Stepančič, who signed the poem with her pseudonym Rodoljubka ('Kin-lover'):

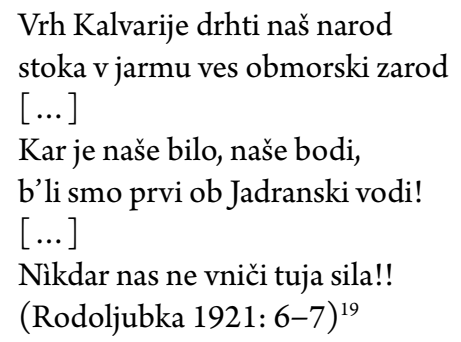

This era is characterised by Slovene Triestine poems in which the authors only talk about the consequences of antagonistic acts that plagued everyday life for Slovene communities in the Triestine area. Paradoxically, this made the antagonists (Italians, personification of evil) the main characters of Slovene narrative poetry, whereas the Slovene characters (personification of good) are helpless victims, who had taken a passive stance and waited, praying and pleading, for the salvation by the heavenly authority. Depictions of Slovene people as slaves in Slovene poetry were also common during this era.

A good example is this excerpt from Slovene poet Karel Širok, entitled Molitev ('Prayer'):

Nekronanega kralja reši nas, Gospod,

krivičnih trum njegovih reši nas, Gospod!

$[\ldots]$

Imamo zemljo, hišo svojo, o Gospod,

a sužnji smo. Na svojih tleh, Gospod

$[\ldots]$

19 Our nation shudders at the summit of Kalvarija / all of the coastal progeny wails in chains [...] What was ours, ours should stay / we were first by the Adriatic waters! $[. .$.$] Never shall the foreign might destroy us!$ 
Ne štej nam v zlo, da se potožimo, Gospod, nekronanega kralja reši nas, Gospod, krivičnih trum njegovih reši nas, Gospod (Širok 1935: 56). ${ }^{20}$

The social standing of Slovenes under the fascist regime contributed to a firm model establishing itself in Slovene poetry, wherein the united Slovene community had a key role. In keeping with this model, Slovene authors did not create narratives in which friendly or romantic ties could develop between "we" (the Slovenes) and "they" (the Italians) or rather, these connections were penned with the intention of collective criticism and embarrassment caused by the firstperson plural subject, who spoke out on behalf of the united Slovene community.

The mentioned literary imagery solidified the depiction of Slovenes as good, downtrodden people, slaves even, and the cause of their suffering was the foreign aggressor (Italians). Upon this basis, drawing inspiration from the socio-political situation of the interwar period, a first-person, often plural subject established itself in Slovene literature during the 1920s and 30s. It spoke out about the tragic "story" of the Slovene people in the Triestine area on their behalf. This "story" began taking shape after the arson at the National Hall, which could also be labelled as a literary myth of Slovene culture in the Triestine area, whose echoes or rather its basic structure can still be found in contemporary literary works. It stems from the legendary idea of the Slovene community's might during the reign of the Austro-Hungarian Empire, when Trieste was the most populous Slovene city and was culturally and economically very important. Consequently, the collective pain of Slovene Triestines is anchored into the narrative. Also preserved is the collective memory of the antagonists, responsible for the loss of the "Slovene Trieste".

The mentioned narrative structure is used in the sonnet cycle entitled $O$ Trst, $t i$ moja večna bolečina! ('Oh, Trieste, My Everlasting Pain!'), written by Janko Samec, one of the best poets from Trieste during the interwar period. As a teacher, he moved from Trieste in the 1920s to the Kingdom of the Serbs, Croats and Slovenes, where this cycle was penned and whose introduction is quoted below:

20 Oh Lord, save us from the uncrowned king, / Oh Lord, save us from his unjust horde! [...] Oh Lord, we have our house and land, / but we are slaves, on our own soil, oh Lord! [...] Do not begrudge us our lament, oh Lord, / Oh Lord, save us from the uncrowned king, / Oh Lord, save us from his unjust horde! 
TOROŠ

O Trst, ti moja večna bolečina!

Jaz nosim te vse dni globoko v sebi

in $\mathrm{v}$ srcu vedno hrepeneč po tebi, vem, da ne prideš več mi iz spomina!

(Uvodna; Samec 1981: 18) ${ }^{21}$

As already mentioned, the mythic story of Trieste was also formed on the pages of Italian literature in the interwar period, set during the reign of the AustroHungarian Empire. The image of the "Habsburg Trieste" was saturated with nostalgia for the former significance of Trieste for the Empire. Within this idealised image some Slovene characters are scattered, not as the opponents of an Italian Trieste, but as folkloric characters from the surrounding countryside, although their nationality is not mentioned. An example of such characterisation can be found in Carlo Mioni's poem Ieri e ogi ('Yesterday and Today'):
I oci me li sfrègolo
E vedo tuto intorno:
Done del pan e mlècherze
E sin la lavandere
A bordo dele eletriche
(Mioni 1933: 14-16). ${ }^{22}$

In the quoted excerpt we find the Italicised Slovene dialect word mlecherze (mlekarice: women who carried and delivered milk) with which he denoted the lingual and cultural belonging of peasant women (different in its attitude towards Italian culture), who sold bread and milk in Trieste.

We can establish that both Slovene and Italian Triestine literature from the first half of the $20^{\text {th }}$ century was characterised by national stereotypes, shaped by the influence and needs of the non-literary socio-political situation. The Italian Triestine literature most frequently depicted the Italians as the inheritors of the Roman culture (auto-stereotype), wherein it highlights their combativeness and burning desire to "free" Trieste from its Austro-Hungarian prison. On the other hand, the Slovene Triestine literature depicted the Slovenes (native culture) after the First World War as "slaves" and simultaneously as the determined defenders of their land, who are also fully aware of their powerlessness against the immoral aggressor and cruel master (Italian hetero-stereotype) and so often call upon the

${ }^{21}$ Oh Trieste, my everlasting pain! / Always I carry you deep within me / my heart forever yearns for you, / I know that I will never forget you.

22 I rub my eyes /and see around me: / bread-ladies and milk-ladies / even laundresses / on the trams. 
Auto-stereotypes and Hetero-stereotypes in Slovene and Italian Poetry About Trieste

help of imaginary forces (mythical heroes and personified nature in the Trieste region) and God. The Italian Triestine literature mostly depicted the Slovenes before the First World War as an inferior people, often referred to by the word "ščavi" (Slovene heterostereotype). After the First World War, the Slovenes are depicted merely as the residents of the former Austro-Hungarian Trieste, meaning they were part of the narrative surrounding Trieste, only in when the narrative was set before the First World War. In this case, the pre-war Slovene stereotypes appear, also depicted as part of the literary myth of the "Habsburg" Trieste, namely as the folkloric characters from the surrounding countryside.

To understand these constructs we must first understand the circumstances surrounding their formation. The latter seems especially important as part of literary didactics, to help younger generations avoid uncritically absorbing stereotypes moored in literary works.

\author{
Ana Toroš \\ Ana.Toros@ung.si \\ Fakulteta za humanistiko \\ Univerza v Novi Gorici \\ Vipavska 13 \\ 5000 Nova Gorica \\ SLOVENIJA / SLOVENIA
}

\title{
Sources and bibliography
}

Aškerc, A. 1989. Zbrano delo IV. Ed. Vlado Novak. Ljubljana: DZS (Zbrana dela slovenskih pesnikov in pisateljev).

Bezin, E. et al. 2012. Kako lep je Trst. Prvi slovenski vodnik po Trstu in okolici. Trst: ZTT.

Cornet - Corrai, R. 1938. Trieste mia!: versi in dialetto triestino. Disegni originali di Carlo Bruna (Originalne slike Carla Bruna). Trieste: Borsatti.

Doria, M. 1988. Storia del dialetto triestino: con una raccolta di 170 testi. Trieste: Italo Svevo. Gianni, M. 1919. Alto tradimento. Bologna - Trst - Rocca S. Casciano: Cappelli.

Gregorčič, S. 1947. Zbrano delo I. Ed. France Koblar. Ljubljana: DZS (Zbrana dela slovenskih pesnikov in pisateljev).

Gruden, I. 1920. Primorske pesmi. Ljubljana: Zvezna tiskarna.

Kacin Wohinz, M. et al. 2000. Zgodovina Slovencev v Italiji 1866-2000. Ljubljana: Nova revija (Zbirka Korenine / Nova revija).

Mioni, C. 1933. Sogni e ricordi. Trieste: Tip. Moderna.

Mioni, C. 1934. Lanterna magica. Trieste: Tip. Moderna.

Pageaux, D. 2008. Uvod v imagologijo. Transl. Gregor Perko. - Daniel-Henri Pageaux: Imagološke razprave. Ed. Tone Smolej. Ljubljana: Institutum Studiorum Humanitatis, Fakulteta za podiplomski humanistični študij (Knjižna zbirka Documenta; 17), 17-52. 
TOROŠ

Pletikosić, I. 2006. Revizije popisa prebivalstva Trsta iz leta 1910. - Annales: anali za istrske in mediteranske študije = annali di Studi istriani e mediterranei = annals for Istrian and Mediterranean studies. Series historia et sociologia, 477-482.

Rodoljubka [Marica Gregorič Stepančič] 1921. K obletnici 13. julija. - Jadranka 7, 6-7.

Samec, J. 1981. Sen morja. Trst - Ljubljana: ZTT - CZ.

Širok, K. 1935. Kapelica. Ljubljana: Akademska založba.

Stergar, R. 2005. Podoba Italijanov pri Slovencih (Ob italijanski napovedi vojne Avstro-

Ogrski). - T. Smolej (ed.): Podoba tujega v slovenski književnosti. Podoba Slovenije in Slovencev v tuji književnosti. Ljubljana: Oddelek za primerjalno književnost in literarno teorijo Filozofske fakultete Univerze v Ljubljani, 102-115.

Tavzes, M. et al. 2002. Veliki slovar tujk. Ljubljana: CZ.

Toroš, A. 2011. Podoba Trsta in Tržaškega v slovenski in italijanski poeziji prve polovice 20. stoletja, (Humanistika). Nova Gorica: Univerza.

Vivante, A. 1984. Irredentismo adriatico. Trieste: Italo Svevo.

Volpi Lisjak, B. 2010. Tržaško morje: kraška obala, mesto in vasi: prezrti del zgodovine Slovencev. Koper: Libris (Zbirka Morje; 4).

Weiss, O. 1909. [Footnotes]. - O. Weiss: El scovazon. Trieste: Vram. 